\title{
The European Union's decision to introduce a financial transactions tax (FTT) in 2011-2012
}

\author{
Lucinda Cadzow \\ Monash University \\ lccad1@student.monash.edu
}

The Eurozone was left reeling after the sovereign debt crisis in 2009. Huge bailouts to governments and banks to stabilise the Euro ensued and policymakers within the European Union (EU hereafter) sought to find a solution to the vulnerability of the Euro to volatility induced by currency speculation. ${ }^{1}$ In 2011, a Financial Transactions Tax (FTT hereafter) was proposed by the European Commission as both a method of recovering some of the funds that were lost due to the remedial fiscal policies that were implemented after the crisis, and also to be used as a corrective mechanism in order to reduce the volatility apparently caused by high frequency trades and currency speculators. ${ }^{2}$ The tax was to apply to trades in stocks and bonds, as well as derivatives, at a harmonised minimum of 0.1 per cent and a 0.01 per cent tax rate respectively. 3

However, the controversial tax garnered opposition from within the EU from the outset and currently only ten countries within the EU (the ECP-10) have agreed to pursue the tax, albeit with waning interest and growing concern since the initial proposition. 4 Critics of the tax argue that the scope of the tax has far reaching consequences: the FTT applies to transactions concerning any party from that tax jurisdiction meaning that it will apply outside the countries that have pursued the tax. This could have the effect of shifting transactions away from the EU and thus losing the revenue gaining potential of the tax. The tax has also been criticised on the basis that the corrective potential of the tax is limited as the incidence of the tax is

\footnotetext{
${ }^{1}$ John Grahl, Photis Lysandrou, 'The European Commission's Proposal for a Financial Transactions Tax: A Critical Assessment,' Journal of Common Market Studies, (2014): 234.

${ }^{2}$ See: Stephan Schulmeister, Margit Schratzenstaller, Oliver Picek, 'A General Financial Transaction Tax: Motives, Revenues, Feasibility and Effects,' (Research Study) Austrian Institute of Economic Research, (2008): 53.

${ }^{3}$ European Commission, 'Proposal for a Council Directive on a common Financial Transaction Tax and amending Directive 2008/7/EC,' (28/09/2011):

http://ec.europa.eu/taxation_customs/resources/documents/taxation/other_taxes/financial_sector/com(2011)594_en.pdf :(specifically Art. 8.2) p.19-20

${ }^{4}$ See: Ott Ummelas, Rebecca Christie, 'EU Financial-Transaction Tax’s Support Wanes on Scope, Ligi Says,' Bloomberg, 19/02/2014: http://www.bloomberg.com/news/print/2014-02-19/eu-financial-transaction-tax-s-support-wanes-on-scope-ligisays.html
} 
likely to fall on pension funds and governments as opposed to the financial sector that it is targeted at. 5

This paper will analyse the FTT as a policy instrument in the EU. It will do so in four parts: first, it will discuss the relevant background to the proposal in the IMF report on FTTs and will then provide an overview of the 2011 EU FTT proposal; second, this paper will evaluate some of the contesting arguments for and against an FTT amongst key member states of the EU, examining the main voices for the tax: France and Germany, and the most vocal opponent to the tax: the United Kingdom. Third, this paper will compare the FTT with possible alternatives to the tax that may or may not have been considered by policymakers in the Commission, such as a tax on financial assets (FAT); and last, this paper will conclude with a discussion on the effects and progress of the FTT, including the legal challenge from the UK in relation to the Council's pursuit of an FTT through enhanced cooperation. Ultimately this paper will find that the issues surrounding the proposal of an EU FTT have had far reaching political and legal consequences, and, once the tax is implemented (scheduled for 1 January 2016), most likely economic consequences beyond the participating member states.

\section{Framing the 2011 FTT: The Monti Report and the G20 IMF Report.}

\section{The IMF Report}

In 2010, G20 ministers commissioned the International Monetary Fund (IMF) to research possible tax instruments designed to curb the volatility induced by currency speculators and reduce the amount of high frequency trades within financial markets. ${ }^{6}$ The report investigated two tax policies: a Financial Transactions Tax (FTT), and a Financial Activities Tax (FAT), both of which will be discussed below.7 An FTT is based upon the assumption that raising the cost of transactions will reduce the incentive for short-term, high-frequency traders to trade in high volumes - an issue that policymakers identified as an important contributing factor to the Eurozone crisis. ${ }^{8}$ Thus, the potential benefits of an FTT are twofold: first, an FTT would have significant revenue-raising capability, given the breadth of the tax base, and second, the tax could have significant corrective potential through raising the cost of transactions, thus providing a disincentive for traders to trade in high volumes as each transaction is to be taxed. ${ }^{9}$ An FTT had to be designed to maintain a

\footnotetext{
${ }^{5}$ See: Patrick Honohan, Sean Yoder, 'Financial Transactions Tax: Panacea, Threat, or Damp Squib?,' The World Bank Research Observer, (2010):153-154; European Commission, 'Staff Working Paper: Impact Assessment

Accompanying the document Proposal for a Council Directive on a common system of financial transaction tax and amending Directive 2008/7/EC (Annex 12), vol.13 28/09/2011: 5

http://ec.europa.eu/taxation_customs/taxation/other_taxes/financial_sector/ftt_background_en.htm

${ }^{6}$ Ross P. Buckley, Gill North, 'A Financial Transactions Tax: Inefficient or Needed Systemic Reform?,' Georgetown Journal of International Law, (2011/2012): 762-763.

${ }^{7}$ See Stijn Claessens, Michael Keen, and Ceyla Pazarbasioglu 'Financial Sector Taxation: The IMF's Report to the G20 and Background Material,' International Monetary Fund, (2010) :

http://www.imf.org/external/np/seminars/eng/2010/paris/pdf/090110.pdf

${ }^{8}$ See European Commission, 'Executive Summary of the Impact Assessment Report on "Instruments for the Taxation of the Financial Sector,' (28/09/2011): 2,

http://ec.europa.eu/taxation_customs/resources/documents/taxation/other_taxes/financial_sector/summ_impact_assesmt_en. pdf

${ }^{9}$ Sigurd Næss-Schmidt, Eva Rytter Sunesen, Martin Bo Hansen, Daniel Mekonnen Ali, 'Tax Elasticities of Financial Instruments, Profits and Remuneration: Review of the Economic Literature, Working Paper no. 30,' Copenhagen Economics
} 
balance between the two objectives - that is, the tax rate had to be low enough so as not to divert trade to other lower tax jurisdictions, but had to be high enough in order for the revenue potential to contribute significantly to public finances. ${ }^{10}$ Proposing such a tax was therefore ambitious from the outset, as the tax would require the willingness of member states to implement a minimum, uniform tax rate, thus ceding further control of tax policy over to the EU, and its potential revenue to the EU budget. ${ }^{11}$

\section{The 2011 EU FTT proposal}

Thus, on 28 September 2011, the European Commission proposed a harmonised Financial Transactions Tax for all member states, outlining the following reasons:

- to prevent the fragmentation of the Single Market that could result from numerous uncoordinated national approaches to taxing financial transactions,

- to ensure that the financial sector made a fair and substantial contribution to public finances, and

- to discourage financial transactions which do not contribute to the efficiency of financial markets or of the real economy. ${ }^{12}$

From the objectives above, it is clear that an FTT was largely framed around the principle of making the financial sector make an equitable contribution to the real economies of states such that the revenue raising capabilities of the sector might be shared in a more socially constructive way. ${ }^{13}$ However, the other main political objective of the 2011 proposal was aimed at strengthening the Single Market by designing a tax policy that sought to harmonise tax rates on the sector at an EU level. This is particularly salient given that several member states already had an FTT of sorts in place at the time of the proposal, while a growing number of member states began looking to implement taxes in the near future. ${ }^{14}$ The tax was, therefore,

(commissioned for EU Commission's Directorate General Taxation Customs Union), (11/09/2012): 36-37

http://ec.europa.eu/taxation_customs/resources/documents/taxation/gen_info/economic_analysis/tax_papers/taxation_paper_ 30_en.pdf

${ }^{10}$ ibid.

${ }^{11}$ In the initial proposal, the Commission pushed for at least some of the tax revenues to be allocated to be used as an 'own resource.' Barry Larking, 'Overview of National Taxation of the Financial Sector,' Derivatives and Financial Instruments: IBFD, (2012): 71.

${ }^{12}$ European Commission, 'The original proposal of 28 September $2011 \ldots$ and its fate,' (2014)

http://ec.europa.eu/taxation_customs/taxation/other_taxes/financial_sector/index_en.htm\#fate; see the full Commission proposal: European Commission, 'Proposal for a Council Directive on a common Financial Transaction Tax and amending Directive 2008/7/EC,' (28/09/2011)

http://ec.europa.eu/taxation_customs/resources/documents/taxation/other_taxes/financial_sector/com(2011)594_en.pdf : 2 .

${ }^{13}$ Larry Elliott, 'At least Hollande and Merkel agree on one thing: a financial transactions tax,' The Guardian, 16/05/2012, : http://www theguardian.com/business/economics-blog/2012/may/15/hollande-merkel-financial-transaction-tax . For an examples see: Robin Hood Tax, : http://robinhoodtax.org.uk - this group is a pro FTT lobby group based within the UK, that has garnered around 1 million supporters.

${ }^{14}$ Christiana HJI Panayi, 'The EU's Financial Transaction Tax, Enhanced Cooperation and the UK's Challenge,' European Taxation, (2013): 358; see also European Commission, 'Tax reforms in EU Member States 2011: Tax policy challenges for economic growth and fiscal sustainability, European Economy 5,' 2011: 37,

http://ec.europa.eu/economy_finance/publications/european_economy/2011/pdf/ee-2011-5_en.pdf ; also 'FTT - additional analysis of impacts and further clarification of practical functioning (fact sheet), 'DG Taxation and Customs Union, 04/05/2012

http://ec.europa.eu/taxation_customs/resources/documents/taxation/other_taxes/financial_sector/fact_sheet/technical_fiches. pdf: section 6 . 
promoted as an important mechanism for mitigating the fragmentation of the Single Market that would be brought about by discrepant tax rates throughout the EU, the effects of which would arguably have distortive effects on financial markets within the EU, and promote taxation competition between member states. ${ }^{15}$

In order for this tax to be truly effective however, policymakers recognised that the end goal was to push for a global tax on financial transactions - thus the Commission acknowledged the need for an internationally coordinated taxation regime so as to mitigate international 'leakages,' or the migration of funds to jurisdictions outside the EU where the tax would not apply. ${ }^{16}$ Although this seemed like an ambitious task given that such a tax would require a level of consensus regarding the design and implementation of a tax across extremely disparate national economies and financial markets, and would require the overcoming of collective action issues on a politically sensitive topic, the tax was pushed at an EU level as policymakers rationalised the unilateral FTT so as to provide the impetus for other states to follow suit eventually. ${ }^{17}$

\section{Beneficial or Threatening? Responses to the proposal}

\section{EU FTT as beneficial: France and Germany}

Germany has been particularly instrumental in pushing for the implementation of the EU FTT, although this can be attributed to domestic political factors as much as it has been about deeper integration of the Single Market. Indeed the SDP (Social Democratic Party) and the Greens were supportive of the implementation of an FTT, as the revenue-raising objectives of the tax were at the forefront of German policymakers' minds given that Germany had footed much of the bill for bailing out Eurozone banks and member states. ${ }^{18}$ Although the EU-wide 2011 proposal of an FTT was stalled due largely to opposition from the UK and Sweden, the subsequent and revised FTT in 2013 became an important election topic; by 2013, the implementation of the FTT became even more of a politically sensitive topic in Germany as the looming vote on the Fiscal Compact placed pressure on Chancellor Merkel and the CDU (Christian Democratic Union), deadlocked in German parliament, to agree to Greens and SDP calls for support of the tax in order to obtain their votes for the ratification of the Compact. ${ }^{19}$

\footnotetext{
See: European Commission, 'Proposal for a Council Decision authorising enhanced cooperation in the area of the financial transaction tax,' 25/10/2012: 6-7,

http://ec.europa.eu/taxation_customs/resources/documents/taxation/com_2012_631_en.pdf

${ }^{15}$ ibid; see also, European Commission, 'Commission Staff Working Paper: Executive Summary of the impact assessment (Accompanying the document: Proposal for a Council Directive on a common system of financial transaction tax and amending Directive 2008/7/EC) (28/09/2011): 3,

http://www.europarl.europa.eu/registre/docs_autres_institutions/commission_europeenne/sec/2011/1103/COM_SEC(2011)1 103_EN.pdf ; and European Commission, 'Communication from the Commission to the European Parliament, the Council, the European Economic and Social Committee and the Committee of the Regions: Taxation of the Financial Sector,' 7/10/2010:4, http://ec.europa.eu/taxation_customs/resources/documents/taxation/com_2010_0549_en.pdf.

${ }^{16}$ Panayi, 'The EU's Financial Transaction Tax, Enhanced Cooperation and the UK's Challenge:' 358; Honohan, Yoder, 'Financial Transactions Tax: Panacea, Threat, or Damp Squib?:'152; see also: Polly Curtis, 'Is the City really under threat from Europe?,' The Guardian, 08/12/2011 http://www.theguardian.com/global/reality-check-with-pollycurtis/2011/dec/08/europeanbanks-conservatives?guni=Article:in\%20body\%20link

${ }^{17}$ Panayi, 'The EU's Financial Transaction Tax:'358.

${ }^{18}$ 'Expanded Euro Bailout Fund clears hurdle in Germany,' New York Times, 31/08/2011, http://www.nytimes.com/2011/09/01/business/global/expanded-euro-bailout-fund-clears-hurdle-in-germany.html?_r=0 19The Economist, 'Taxing Financial Transactions: Heading for an Own Goal,' 13/06/2012, http://www.economist.com/blogs/freexchange/2012/06/taxing-financial-transactions ; 'Rapid Outcome: Germany wants Transaction Tax by mid 2012,' Der Spiegel, 12/03/2012 http://www.spiegel.de/international/europe/rapid-outcome-
} 
Whilst in France, a proposed national FTT was implemented in 2012, amid what some analysts argued was a bid for votes by (then) president, Nicolas Sarkozy, in the upcoming presidential elections. ${ }^{20}$ Both France and Germany highlight the importance that domestic public opinion and political pressures also had on the decision to pursue the tax, despite calls from the financial sector, and pressure from financial lobbies that the tax was ultimately harmful to long-term economic interests. ${ }^{21}$

\section{EU FTT as threatening: UK}

Whilst states such as Germany and France painted the proposed tax as being a useful policy instrument to raise revenue and ensure market stability, the United Kingdom has been highly critical of the tax, with members of the House of Lords arguing that the tax is going to fall unfairly and unevenly on different member states due to the location of the largest financial centres in the EU; Prime Minister David Cameron called the proposed tax "madness", after vetoing the proposal in December 2011. ${ }^{22}$ Given that the City of London is the biggest financial centre in Europe, much of the taxation would be collected from transactions conducted on the London stock exchange, leading Stuart Fraser, Policy Chairman of City of London Corporation, to argue: "clearly, with most of the revenues coming from the UK, a European FTT would be more of a tax on London than on the EU." 23

This point remains open to dispute given that the design of the tax meant that the geographical location of the transaction was not the sole basis upon which the tax could be levied - rather the tax would apply to EU based parties and instruments. ${ }^{24}$ However, the concentration of trading does seem to be at issue here: the detrimental effects that the tax would have would be in reducing the amount of transactions taking place within big financial centres within the EU, notably, Frankfurt and London. ${ }^{25}$ This highlights another political and financial issue at stake for the United Kingdom: the 2011 proposal called for the FTT to be a replacement of existing FTTs already in place in member states, therefore, the UK would have to abolish its stamp duty, a source of national revenue generation for the UK for since $1986 .{ }^{26}$ Imposing an EU FTT would thus mean that the UK would lose this exclusive source of revenue, and instead the revenue (admittedly projected to be far greater due to the EU-wide

\footnotetext{
germany-wants-transaction-tax-by-mid-2012-a-820779.html ; see also Willem Van Veen, 'How the Financial Transaction Tax Affects Pension Funds,' Derivatives and Financial Instruments: IBFD, (2013):16.

${ }^{20}$ Rupert Neate, 'France Plans Tobin Tax on financial transactions,' The Guardian, 31/01/2012, http://www.theguardian.com/business/2012/jan/30/france-tobin-tax-nicolas-sarkozy

${ }^{21}$ Martin Hesse, Christoph Pauly, 'Financial Lobby in revolt: How much longer can transaction tax be delayed?,' Der Spiegel, 20/03/2012, http://www.spiegel.de/international/europe/financial-industry-lobbyists-delay-financial-transactiontax-a-822186.html.

${ }^{22}$ Panayi, 'The EU's Financial Transaction Tax, Enhanced Cooperation and the UK's Challenge:' 364; Larry Elliott, Jill Treanor, 'Davos: David Cameron urges Eurozone to take 'bold and decisive action,'” The Guardian, 26/01/2012, : http://www.theguardian.com/business/2012/jan/26/davos-david-cameron-eurozone-wef ; Larry Elliott, Graeme Weardon, 'Merkel and Sarkozy push for greater European cooperation,' The Guardian, 17/08/2011, : http://www.theguardian.com/business/2011/aug/17/angela-merkel-nicolas-sarkozy-

summit?guni=Article:in\%20body\%20link

${ }^{23}$ Stuart Fraser, 'Letters: How Can You Tax Transactions that are no longer there?,' Financial Times, October $6^{\text {th }} 2011$, http://www.ft.com/intl/cms/s/0/65ab35d4-ef7c-11e0-941e-00144feab49a.html\#axzz327xyr331; it is worth noting that the UK was supportive of a global FTT proposal, but highly critical of the EU wide proposal.

${ }^{24}$ Vogel, Cortez, 'The Commission's Proposal To Introduce an EU Financial Transaction Tax:' 80.

${ }^{25}$ ibid: 82 .

${ }^{26}$ Vogel, Cortez, 'The Commission's Proposal To Introduce an EU Financial Transaction Tax:'82.
} 
scope of the tax), would instead go directly to the EU budget, to which the UK would contribute more than other member states, meanwhile there would be no guarantee that the UK would receive a proportionate share of their contribution back in the form of EU spending. ${ }^{27}$ Thus, implementing an EU FTT would mean ceding national control of revenue raising through taxation of the domestic financial sector, meaning that some member states would stand to lose out more than member states with smaller financial centres. ${ }^{28}$ Meanwhile, the far-reaching scope of the tax would reduce the efficiency and size of the City, thus diverting trade to other financial centres around the world. ${ }^{29}$

Due to the opposition to the tax led by the UK, by September of 2012, only 11 member states decided to pursue the tax outlined in the original Commission proposal through 'enhanced cooperation,' after the initial EU wide proposal failed to receive the required support in the European Council. ${ }^{30}$ As this is a last resort procedure, adoption of enhanced cooperation with regard to the FTT shows the conflict of interests within the EU over the tax. Interestingly, the tax has been largely opposed by member states that have traditionally been more on the side of 'euroscepticism,' for example: the UK, Sweden and Denmark. ${ }^{31}$ Thus, the proposal of an FTT speaks of a wider and historical political dynamic within the European Union, with France and Germany, typically advocates for deeper integration, forging ahead with the FTT, and the UK, typically eurosceptic, vehemently opposing the proposition.

\section{Limitations of the 2011 Financial Transactions Tax: possible alternatives and issues}

\section{Narrow based FTT}

Whilst the September 2011 proposal advocated for the broadest tax base, a narrower based FTT could also have been considered. The "poster child" for this type of tax (narrow based) is the United Kingdom's Stamp Duty or Stamp Duty Reserve Tax (SDRT). ${ }^{32}$ This tax has proven largely successful in terms of it not having overtly distortive effects on financial activities, even though the tax is levied at a higher rate than the proposed EU FTT: $0.5 \%$ on transactions on shares (and not derivatives), traded on the UK stock exchange, thus the tax applies only to transactions taking place within the UK. 33 However, even though the UK has been largely successful with this tax for decades, the reason is largely that the taxation base is narrower than the

\footnotetext{
${ }^{27}$ ibid.

${ }^{28}$ ibid; Peter Kavelaars, 'Bank Taxes in Forms and Sizes: EC Opts for FTT,' Intertax, (2012): 403.

29Næss-Schmidt, et al., 'Tax Elasticities of Financial Instruments, Profits and Remuneration: Review of the Economic Literature, Working Paper no. 30:' 36.

${ }^{30}$ Only Belgium, Germany, Estonia, Greece, Spain, France, Italy, Austria, Portugal, Slovenia and Slovakia pushed for the tax. See Council of the European Union, 'Financial Transactions Tax: Council Agrees to Enhanced Cooperation,' (Press Release) (2013): http://www.consilium.europa.eu/uedocs/cms_data/docs/pressdata/en/ecofin/134949.pdf

${ }^{31}$ See Stephen George,' Britain: Anatomy of a Eurosceptic state,' Journal of European Integration, (2007): 18-20 for an analysis of the UK's euroscepticism.

${ }^{32}$ Vogel, Cortez, 'The Commission's Proposal To Introduce an EU Financial Transaction Tax:' 78.

${ }^{33}$ Martin Hesse, Christoph Pauly, 'Financial Lobby in revolt: How much longer can transaction tax be delayed?,' Der Spiegel, 20/03/2012, http://www.spiegel.de/international/europe/financial-industry-lobbyists-delay-financial-transactiontax-a-822186.html
} 
EU FTT, the trade off then is that the revenue-raising potential is compromised. ${ }^{34} \mathrm{~A}$ narrow based tax is therefore not conducive to the second goal of the 2011 proposal: making the financial sector contribute to public finances. Thus the Commission pushed for a wider based FTT, inclusive of derivatives and OTC transactions with a residence principle attached that meant that any EU company, institution would be subject to the tax (with exemptions granted to transactions made by central banks; and the raising of capital through primary market transactions i.e. issuance or subscription or initial purchase of shares and bonds.) 35

\section{FAT}

Alternative taxation mechanisms were also investigated by the EU - chief among these was a Financial Activities Tax (FAT). A FAT differs from an FTT in that it taxes profits and remuneration. ${ }^{6}$ The Impact Assessment (IA) of the 2011 EU FTT proposal compares the two tax instruments (FTT and FAT) to find that the FTT is more favourable in terms of revenue raising. ${ }^{37}$ Denmark, France and Italy each have an operative FAT of sorts, and an FAT may prove to be more viable as national taxation strategy rather than an EU wide tax: as the tax base is purely financial institutions, the tax is quite complex to implement and would require higher administrative costs. ${ }^{38}$ However, the FAT would arguably be more evenly distributed amongst due to the tax base being institutions and not transactions. 39 Ultimately, given that the dual objectives of policymakers was to raise revenue and correct the market distortions and volatility in financial markets due to excessive automated trading, an FTT was deemed a better tax instrument as it sought to be a corrective device too. 40

\section{Issues with the Proposed EU FTT}

One issue with an FTT is that it requires a large degree of coordination and consensus in order for it to be effective. It is evident, however, that even within the $\mathrm{EU}$, this consensus is not possible, let alone harmonisation between the EU and other states on tax issues. ${ }^{41}$ In order for an FTT to realise significant revenue-raising potential, the tax must be implemented across a broad range of member states so that the tax base is not eroded and financial markets are not distorted through

\footnotetext{
${ }^{34}$ Kavelaars, 'Bank Taxes in Forms and Sizes:' 403, 405

${ }^{35}$ Sandy Bhogal, Alexandria Carr, James Taylor, 'The FTT and European Sovereign Debt,' International Financial Law Review, (2013): http://search.proquest.com/docview/1431637692?accountid=12528

${ }^{36}$ Kavelaars, 'Bank Taxes in Forms and Sizes:' 404; see also The European Commission, 'Financial Transaction Tax: Staff Working Document No. 25,' (2010): section 3.2, :

http://ec.europa.eu/taxation_customs/resources/documents/taxation/sec_2010_1166_en.pdf

${ }^{37}$ See European Commission, 'Staff Working Paper: Impact Assessment

Accompanying the document Proposal for a Council Directiveon a common system of financial transaction tax and amending Directive 2008/7/EC (Annex 8- Policy Options).

${ }^{38}$ Kavelaars, 'Bank Taxes in Forms and Sizes:' 404.

${ }^{39}$ ibid. The IA identified potential revenues for a FAT at an 'illustrative rate of 5\%' to be between EUR 9.3 billion and EUR 30.3 billion, while the FTT was initially estimated to potentially raise between EUR 16.4 billion and EUR 400 billion, however, subsequent estimations for the current FTT proposal generally predict revenues around the EUR 30-35 billion mark see: European Commission, 'Commission Staff Working Paper: Executive Summary of the impact assessment:' 5; see Taxation and Customs Union, 'Taxation of the Financial Sector: Financial Transaction Tax, Proposal of 14 February 2013,' http://ec.europa.eu/taxation_customs/taxation/other_taxes/financial_sector/index_en.htm\#fate .

${ }^{40}$ European Commission, 'Commission Staff Working Paper: Executive Summary of the impact assessment:' $6 .$.

${ }^{41}$ Rainer Buergin, Brian Parkin, 'Merkel Coalition Signals Retreat on Broad Financial- Market Tax,' Bloomberg, 03/02/2014

: http://www.bloomberg.com/news/print/2014-02-03/merkel-coalition-signals-retreat-on-broad-financial-market-tax.html
} 
migration to lower, or no tax jurisdictions. ${ }^{42}$ Another issue is in where the actual economic incidence falls: proposing a tax in which the incidence falls on the financial sector looked, to policy makers and to the public, as if the financial sector was finally getting the retribution that they deserved from the Eurozone crisis. 43

The Commission's Staff Working Paper on Financial Transaction Tax 2010 highlights that the corrective measures of a broad based FTT are problematic: while the amount of trading in secondary markets is likely to be reduced, thereby reducing the amount of purely speculative and 'noise' trading, other transactions that occur within the secondary market are often cited as being vital to the function of the real economy by reducing the costs of capital, thus, the real incidence, the economic, not just the legal has been called into question from the very outset. 44 The abovementioned paper recommends against the adoption of a broad based FTT on the basis that the real incidence (the economic burden) is not for certain going to fall on the financial sector:

In the context of a Financial Transactions Tax, the economic incidence of the tax could fall either on traders, on stock exchanges, on companies and governments (via higher capital costs) or on final consumers via higher prices for financial services. 45

The 2011 Impact Assessment on the EU FTT also supports this point, finding that:

All in all, although the economic incidence of the tax instruments under analysis remains uncertain ex ante, part of the tax burden is likely to fall on final consumers of financial services ... All in all ... the FTT is likely to turn out not effective "at retrospectively targeting those who caused, or profited from, the recent financial crisis.” 46

Picking up on this point, the United Kingdom has also argued against the implementation of a broad based FTT on the basis that the incidence could eventually be detrimental to pension funds. 47 Indeed, the original 2011 proposal an

\footnotetext{
${ }^{42}$ Panayi, 'The EU's Financial Transaction Tax, Enhanced Cooperation and the UK's Challenge:' 358; Honohan, Yoder, 'Financial Transactions Tax: Panacea, Threat, or Damp Squib?:'152.

${ }^{43}$ The European Commission, 'Financial Transaction Tax: Staff Working Document No. 25,': Douglas A. Shackleford, Daniel N. Shaviro, Joel Slemrod, 'Taxation and the Financial Sector,' Taxation and the Financial Crisis, (Oxford:2012): 153.;

${ }^{44}$ See: The European Commission, 'Financial Transaction Tax: Staff Working Document No. 25,' (2010), : http://ec.europa.eu/taxation_customs/resources/documents/taxation/sec_2010_1166_en.pdf : see specifically 4.2, 'The economics of FTT;' The European Commission's Staff Working Paper on Financial Transaction Tax 2010 highlights that it is often difficult to assess the difference between speculative and non-speculative transactions, or whether transactions are "beneficial or harmful" trades based solely on the timeframe within which they take place; Grahl, Lysandrou, 'The European Commission's Proposal for a Financial Transactions Tax:' 242; The European Commission, 'Financial Transaction Tax: Staff Working Document No. 25,' (2010), :

http://ec.europa.eu/taxation_customs/resources/documents/taxation/sec_2010_1166_en.pdf : see specifically 4.2, 'The economics of FTT.'

${ }^{45}$ The European Commission, 'Financial Transaction Tax: Staff Working Document No. 25,' (2010), : http://ec.europa.eu/taxation_customs/resources/documents/taxation/sec_2010_1166_en.pdf : see specifically 4.2, 'The economics of FTT.'

${ }^{46}$ European Commission, 'Staff Working Paper: Impact Assessment,' 28/09/2011, (Annex 12): 5.

${ }^{47}$ George Osborne,' Correspondence: Letter from the Chancellor to the Chief Executive of the European Banking Federation,' HM Treasury, 05/06/2013,

https://www.gov.uk/government/uploads/system/uploads/attachment_data/file/205346/letter_cx_guidoravoet_050613.pdf
} 
EU FTT affected a broad range of financial institutions: from investment firms to pension funds and commercial banks. 48

Finally, some critics have argued that an FTT could further render the European banking system at risk in global financial markets through the design of the tax: whilst the original Tobin Tax was directed at foreign exchange transactions, the proposed EU FTT did not apply to foreign exchange swaps (whereby banks collateralise short-term borrowing of foreign currency through the use of the US dollar).49 Instead, as Grahl and Lysandrou argue, the EU FTT goes against the principle of a Tobin Tax by "conferring a tax advantage" on foreign exchange swaps, as the scope of the tax was to include repo agreements, thus reducing the liquidity of bond markets and fostering the European banking system to be even more reliant on US credit conditions. $5^{\circ}$ This could in effect render European markets even more vulnerable to fluctuations in US markets, thus reducing even more the amount of autonomy of European banking institutions vis-à-vis global systemic conditions. ${ }^{51}$

\section{The FTT since 2012: assessing the FTT against original policy objectives}

\section{UK's legal challenge of the use of enhanced cooperation}

In April of 2013, the United Kingdom, amid parliamentary pressure from the House of Lords, launched a legal action against the Council, arguing that the mechanism of enhanced cooperation in relation to the FTT was illegal, and contravened article 327 of the TFEU, stating that the authorisation of enhanced cooperation in this area would have "extraterritorial effects that will fail to respect the competences, rights and obligations of the Non-Participating States"; that the action was unlawful on the grounds that the measure would have "extraterritorial effects for which there is no justification in international customary law"; and that the Council's decision contravened article 332 of the TFEU as implementation of an FTT would incur costs for Non-Participating States. ${ }^{2}$

However, the UK's appeal to the Court of Justice was quashed on 30 April 2014, and the remaining ten member states participating in the tax have pressed to implement the 2013 FTT in from 1 January 2016, although implementation of the tax is to be a phased approach, with only "shares and some derivatives" to be initially taxed.53 Arguably, the use of enhanced cooperation amongst ten member states, whilst the remaining 18 member states have opted out of pursuing the tax, shows that the first point of the rationalisation of the proposal - that of a harmonised approach to

\footnotetext{
${ }^{48}$ Grahl, Lysandrou, ‘The Commission's Proposal for a financial transactions tax:'236.

${ }^{49}$ ibid:245-246.

${ }^{50}$ ibid; see also, Bhogal, et al., 'The FTT and European sovereign debt'

${ }^{51}$ Grahl, Lysandrou, 'The Commission's proposal for a financial transactions tax:' 245-246.

${ }^{52}$ Court of Justice of the European Union, 'Action brought on 18 April 2013 - United Kingdom of Great Britain and Northern

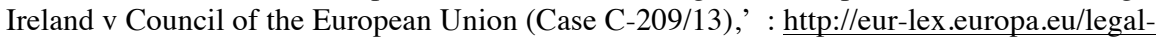
content/EN/TXT/?qid=1400306914888\&uri=CELEX:62013CN0209

${ }^{53}$ Angela Monaghan, 'George Osborne bristles as EU moves closer to financial transaction tax,' The Guardian, $6^{\text {th }}$ May 2014, http://www.theguardian.com/politics/2014/may/06/george-osborne-eu-financial-transaction-tax-legal-challenge . Slovenia did not sign the communiqué, despite pursuing the tax earlier.
} 
taxation of the financial sector to avoid fragmentation - has largely been a failure.54 Moreover, the revenue generating capabilities of the 2011 EU FTT have been significantly diminished as the tax base of transactions was eroded due to the nonparticipation of 18 states, with the biggest financial centre, the City of London, opting out of the tax.55 Whilst this was circumvented by the ECP-10 states pursuing the tax by including a revised 'issuance principle' so that transactions involving parties from non-participating countries trading in financial instruments from a participating member state were liable to be taxed, the initial 2011 proposal obviously left this clause out on the presumption that the tax would be EU wide in scope. In policy terms, the addition of an issuance clause in the 2013 proposal can be largely viewed as a failing of the second justification of the proposal: ensuring that the financial sector would make a fair and substantial contribution to public finances. 56

Moreover, although the advancement of an FTT is a political win for the pro tax member states such as France and Germany, it is unlikely that the implementation of an FTT will set the global standard for a harmonised taxation regime, indeed, Van Vooren argues that the implementation of a global tax would need something of a global "political, legal and institutional revolution." 57 The United States has reinforced this view, stating that they do not support the implementation of an FTT, arguing at the time, that the imposition of a tax on financial transactions would be detrimental to the ability of governments to access much needed capital, as such a tax would raise the cost of capital through reducing the efficiency of financial activity..$^{8}$ Without the most significant international player even indicating support for a tax, the global end goal of the tax either looks to be rather utopian, or perhaps as if it signals empty political rhetoric on the part of policymakers in order to garner public support for the tax. 59

This has important consequences for the regional implementation of such a tax, for although it is too early to assess the actual consequences of the tax, the fact the tax is not to be uniformly implemented throughout the G2O states, or even the EU, means there is capacity for the tax to divert transactions to other geographical locations outside the jurisdictions participating in the tax, as the scope of the tax, although 'extraterritorial,' remains porous and tax avoidance seems difficult to stop. ${ }^{60}$ Instead, the FTT may have the negative consequence of redirecting financial trading to other locations - the ramifications of which could include reduced liquidity in money markets, reduced market activity meaning less revenue potential, and increased costs of capital incurred by EU companies as a result. ${ }^{61}$ Another negative impact of the tax may be in the loss of innovation and efficiency in financial markets; a trade off due to the corrective potential of the tax in slowing down high frequency trading. ${ }^{62}$ Finally,

\footnotetext{
${ }^{54}$ European Commission, 'Communication from the Commission:’ 4.

${ }^{55}$ Panayi, 'The EU's Financial Transactions Tax, Enhanced Cooperation, and the UK's Challenge:' 365.

${ }^{56}$ Grahl, Lysandrou, 'The Commission's Proposal for a financial transactions tax:'236-237.

${ }^{57}$ Van Vooren, The European Union's Shaping of the International Legal Order: 330.

${ }^{58}$ Buckley, North, 'A Financial Transactions Tax:' 786.

${ }^{59}$ For example: Martin Hesse, Christoph Pauly, 'Financial Lobby in revolt: How much longer can transaction tax be delayed?,' Der Spiegel, 20/03/2012, http://www.spiegel.de/international/europe/financial-industry-lobbyists-delayfinancial-transaction-tax-a-822186.html

${ }^{60}$ Honohan, Yoder, 'Financial Transactions Tax:' 153;

${ }^{61}$ See Vogel, Cortez, 'The Commission's Proposal To Introduce an EU Financial Transaction Tax:' 83; European Commission, 'Staff Working Paper: Impact Assessment Accompanying the document Proposal for a Council Directiveon a common system of financial transaction tax and amending Directive 2008/7/EC (Annex 16), vol.13 28/09/2011: 7-8, http://ec.europa.eu/taxation_customs/taxation/other_taxes/financial_sector/ftt_background_en.htm

$\overline{{ }^{62}}$ Honohan, Yoder, 'Financial Transactions Tax:' 140-143, 153-154.
} 
on the retributive attributes of the EU FTT: while the idea of a 'Robin Hood Tax' appears to be appealing to the public through making some of the worst perpetrators in the crisis pay, this seems highly unlikely given that the FTT is likely to have far reaching consequences beyond the financial sector that will ultimately affect the end consumer of financial products and services. ${ }^{6} 3$

The 2011/2012 Financial Transaction Tax proved to be a very divisive proposal that has had political and legal ramifications beyond the ten member states that have pursued the tax. Whilst the United Kingdom has protested the tax on legal, economic and political grounds, the use of the enhanced cooperation procedure has shown that the wishes of strongest states in the EU will ultimately be still be respected, even if the overwhelming majority of EU member states do not support a specific policy. With the deep political divisions between member states opposing the tax such as the UK and Sweden, and pro tax states such as France and Germany, the tax has added to the wider political differences between these states on the issue of Single Market integration. ${ }^{64}$ As such, the initial objective of seeking to find collective solutions to the economic effects of the Eurozone crisis, has not been realised, and the very fragmentary national financial taxation policies that the Commission was attempting to avoid have proliferated as the FTT has been stalled by legal challenges and enduring opposition from within the EU. Thus, the 2011/12 EU FTT proposals can largely be considered to be an EU wide public policy failure as it has been delivered at least two years late, and significantly watered down, while having serious and lasting political effects on the cohesion of the Single Market. ${ }^{65}$

\footnotetext{
${ }^{63}$ Douglas A. Shackleford, Daniel N. Shaviro, Joel Slemrod, 'Taxation and the Financial Sector,' Taxation and the Financial Crisis, (Oxford:2012): 153.

${ }^{64}$ See: Ralf Neukirch, Christoph Pauly, Christoph Scheuermann and Christoph Schult, 'Europe's next crisis: Britain losing allegiance to the EU,' Der Spiegel, 15/10/2012; George, 'Britain: Anatomy of a Eurosceptic state.'

${ }^{65}$ Van Veen, 'How the Financial Transaction Tax Affects Pension Funds:' 16.
} 